\title{
Priorities for Brazilian Cooperation in the South Atlantic
}

\author{
Luís Gustavo Guerreiro Moreira
}

\section{INTRODUCTION}

Contemporary changes in the global order point out topics like inter-regionalism, maritime security and South-South cooperation that represent an important research field to understand the new inter-regional dynamics. The Zone of Peace and Cooperation of the South Atlantic - ZPCAS (Zona de Paz e Cooperação do Atlântico Sul - ZOPACAS), emerges within a context of end of a bipolar world in which the South-South cooperation is intensified.

Created in 1986 by the United Nations General Assembly resolution 41/11, ZOPACAS arises from a Brazilian initiative, supported by Argentina, Nigeria and Angola. Presently it comprises 24 member countries and meets a regional demand to secure an environment free of external threats. ${ }^{1}$ The agreement foresees the "necessity to preserve the region from militarization measures, the arms race, the presence of foreign military bases and, above all, nuclear weapons" (UNITED NATIONS, 1986). ${ }^{2}$

Since its beginning, there have been seven Ministerial Meetings: Rio de Janeiro (1988), Abuja (1990), Brasilia (1994), Somerset West (1996), Buenos Aires (1998), Luanda (2007) and Montevideo (2013). In every meeting, the Brazilian strategy was characterized by an effort to define a regime of political coordination. All in all, it was "the manifestation of the African-Atlantic heritage and it

1 ZOPACAS is composed of South Africa, Angola, Argentina, Benin, Brazil, Cape Verde, Cameroun, Republic of the Congo, Ivory Coast, Gabon, Gambia, Ghana, Guinea, Guinea-Bissau, Equatorial Guinea, Liberia, Namibia, Nigeria, Democratic Republic of the Congo, São Tomé e Príncipe, Senegal, Sierra Leoa, Togo, and Uruguay.

2 The Shanghai Cooperation Organization was founded in June, 1996 by China, Kazakhstan, Kyrgyzstan, Russia, Tajikistan, and Uzbekistan. Its main purpose is military cooperation to fight against terrorism, separatism, and extremism, even though they also deal with issues of economic and cultural cooperation. 
Luís Gustavo Guerreiro Moreira

resulted in its assertion as the operational code for all the member countries of that Zone" (PENHA, 2011, p. 219).

ZOPACAS cooperation in the Defense field has as its main objective avoiding the proliferation of nuclear weapons and reducing - or completely eliminating - the military presence of alien forces in the region. In a broad context, the countries that are part of it seek ways of integration starting from economic, commercial, and technical-scientific cooperation, emphasizing, in the case of Brazil, the policies of technical cooperation and of investments beginning with the activities of Embrapa to foster agricultural production; Petrobras' incentive to S\&T; financing of infrastructure through the National Bank for Economic and Social Development (BNDES); and collaboration between the Brazilian Navy (Marinha do Brasil - MB) and the governments of Angola and Namibia, in order to map and explore the ocean floor, and survey its continental shelves.

\section{GEOPOLITICAL THREATS AND CHALLENGES IN THE SOUTH ATLANTIC}

Brazilian prominence in the constitution of ZOPACAS did not come from a power vacuum, but it appeared in a context of conflict with players of the region and others from outside. The founding of ZOPACAS itself, within the scope of the UN, received support of 124 member States, but it met resistance from European countries like Germany, Belgium, France, Holland, Italy, Luxembourg and Portugal that, like Japan, decided to abstain from voting. The United States was the only member State voting against the resolution. Their fear was due to the fact that this resolution might cause difficulty for the freedom of navigation of those countries in the South Atlantic.

Brazilian presence in Africa arises as a high level geopolitical movement, capable of changing the power play in the Continent, that so far had been an almost exclusive area for European exploitation. Under strong objection from the USA, as a reaction to the Brazilian political projection in South America and Africa and by the competition with the Brazilian defense industry in 
some markets, Brazil's prominence in the South Atlantic zone is manifested in various aspects. An important element in Brazilian strategy becomes evident in the domestic effort to link programs of bilateral and multilateral cooperation in defense. Brazil signed a number of agreements of cooperation in defense with Namibia (1994), Cape Verde (1994), South Africa (2003), Guinea-Bissau (2006), Mozambique (2009), Nigeria (2010), Senegal (2010), Angola (2010), and Equatorial Guinea (2010 e 2013). Since 2012, joint military exercises are carried out with the Navy of Benin, Cape Verde, Nigeria and São Tomé e Príncipe and additional exercises with Angola, Mauritania, Namibia and Senegal. In 2013 Brazil implemented another Brazilian naval mission, in Cape Verde. In several countries, Brazil is the main equipment supplier and a partner in military training. According to Abdenur and Souza Neto these actions "aim at strenghtening the maritime identity of the countries of the South Atlantic perimeter, stressing not only their common concerns, but also their perception of the need to protect oceanic resources on both sides of the South Atlantic, especially the pre-salt area." (ABDENUR; SOUZA NETO, 2014, p.18). Such movement was followed by the strong Chinese entry in that continent. The American military offensive in the continent was an answer to it.

Chinese growth increased the country's demand for energy and commodities. The Chinese presence in Africa in search of natural resources was intensified from 2005 on, when approximately one thousand companies were established and hundreds of thousands of Chinese workers went to different countries. In 2009, China surpassed the United States as Africa's largest trading partner.

In December 2015, during the conference for the Forum of ChinaAfrica Cooperation (Fórum de Cooperação China-África - FOCAC), in Johannesburg, the Chinese president Xi Jinping announced an investment package of US $\$ 60$ billion in various African countries in 2016. The package placed the Chinese energy companies in a position that allowed competition with the large multinational companies like Exxon Mobil and Shell, directly interfering with the American interests in the region. 
Luís Gustavo Guerreiro Moreira

Oil geopolitics will undergo significant changes in the next decade. According to the ex-president of Petrobras, Armando Guedes Coelho, in 2025, Brazil will produce an expressive volume of barrels of oil with the pre-salt, followed by a high production from Angola and Nigeria. This will happen simultaneously to the reduction of imports of the product by the United States, with China becoming the largest importer of Middle East oil. Guedes has also anticipated that China will increase oil and gas imports around 40\% (FUTURA..., 2013). Every geopolitical change of the same proportion has clear implications for regional defense.

In his intervention at the plenary session during the last meeting in Montevideo, in 2013, Defense minister Celso Amorim stressed the need to consolidate and extend defense cooperation among member countries, asserting that "Nowadays we live a reality that makes it difficult to say exactly where, how, and what will be the external interventions of conflicts that might arise." (BRASIL, 2013).

Surveillance in the South Atlantic is fragile. The scrapping of naval ships facilitates illegal smuggling activities, piracy (so far not yet identified in the region) and illegal fishing. The limitations of the war navies of the countries in this zone are explicit. Even the Brazilian navy, the largest one among member countries, has serious limitations. Even though the project of the Brazilian nuclear submarine is underway, there is increasing international greed toward recent discoveries of significant oil reserves in the Brazilian pre-salt layer and there is the rise of Nigeria and Angola, the two biggest producers of oil on the African side, the last one counting on the expressive presence of Brazilian workers and companies linked to the mining, oil, and civil engineering sectors (JORGE, 2011). Therefore, the sea linking the Brazilian oil reserves of the Brazilian pre-salt layer to the region of the Gulf of Guinea becomes a new area of geostrategic importance to the Northern powers, being considered a potential global supplier of the oil that used to come from the Persian Gulf. The National Defense Strategy (Estratégia Nacional de Defesa - END) relates the South Atlantic, together with the Amazon Region, the two most important regions from a strategic point of view, making use of cooperation with neighbor countries whenever necessary (BRASIL, 2008). 
The lack of capacity of the countries to provide surveillance to their territorial seas stimulates the continuous presence of countries like England, that holds a considerable number of territories in the South Atlantic, a remnant of its colonial rule. The continental shelves of the countries in the region necessarily pass through the British territorial waters. England holds sovereignty over islands and archipelagoes throughout the South Atlantic. Among the most controversial territories are the Falkland Islands (Ilhas Malvinas), scene of a war in 1982, and of diplomatic tensions between the governments of Cristina Kirchner and David Cameron in 2015 related to England's claim to oil exploration in the region.

The interventionist pretensions of military instruments such as US Africa Command (AFRICOM), created in 2007, make use of security strategies to control "empty spaces", like the Sahel, on the grounds that locations that have not yet been used by global terrorist groups may be used as spaces for mobilization and training ${ }^{3}$ (BERNARDINO, 2015, p.180). In addition, the reactivation of the U.S. Fourth Fleet by the USA, that happened one year after AFRICOM, uses the argument of security cooperation and fight against terrorism as a pretext. Interventionist actions camouflaged as processes of asymmetrical cooperation arouse distrust in African and South American governments. According to the Brazilian Defense Minister's words "The absence of immediate military threats does not justify thoughtlessness regarding the possibility that we may be affected by crises with an impact on defense and security, even against our will" (AMORIM, 2012). The minister ponders that, "due to the fluidity of international relations, we have to be prepared for a potential external threat and build a strong defense industry as part of a strategy of dissuasion that ensures peace in the South Atlantic" (AMORIM, 2012).

3 The "Pan-Sahel" initiative was "an effort led by the USA to help Mali, Niger, Chad, and Mauritania detect and respond to a suspicious movement of people and assets within their borders through training, equipment, and cooperation. In 2005 it was substituted by the "Trans-Saharian Counter-Terrorism" initiative, and in 2008 incorporated to AFRICOM. 
Luís Gustavo GuerREIRO MoreIRA

\section{BRAZILIAN PERFORMANCE}

Brazilian foreign trade depends, to a large extent, on the exportation of raw materials. In fact, commodities respond for almost half of the country's exports. Minerals, as well as oil products and fuel, are the main export products. Because some of the largest Brazilian companies are specialized in the extraction of oil and mineral resources, most of the ones investing in Africa are also focused on that sector. Brazil benefits from expertise in the exploration of natural resources and from geological similarities with several countries in Africa. The National Bank for Economic and Social Development (Banco Nacional de Desenvolvimento Econômico e Social - BNDES) helped finance these companies and they expanded their activities in Africa in the last decade, thus diversifying their production locations and increasing their international importance.

The expansion of Brazilian presence in the South Atlantic occurs without tensions with neighboring countries. The challenge Brazil faces is not limited to the operation of its companies, but to the coordinated combination between dissuasion and cooperation as well. Regional integration will only bring results if common policies of defense and of military and economic cooperation are combined. Recalling the 2005 UN Summit, at a time when the responsibility of each Member State to protect its population from genocide, war crimes, ethnic cleansing, and crimes against mankind were stressed, the Montevideo Declaration recognized in its text Brazil's contribution, through the concept "Responsibility as Protection" as a complement to the concept "Responsibility to Protect":

[...] special attention must be given to the interdependence between security and development, as they mutually support each other and are fundamental to attain sustainable peace. We emphasize that many conflicts have a socio-economic component, that normally aggravates other ways that drive conflict. (ZOPACAS, 2013).

Within the scope of the ZOPACAS there are mechanisms established for multilateral cooperation in their action plans 
(it is worth mentioning Montevideo, 2013) as a way to intensify the action of the Member States. However, here we notice that bilateral cooperation prevails, leaving multilateralism in the background. Therefore, the projection of national interests are, to a great extent, the reason for Brazilian action in the inter-regional cooperation with Africa.

[...] Brazilian foreign policy uses SouthSouth cooperation in an instrumental way, having the purpose of projecting Brazil's influence abroad, of creating new economic opportunities and political partnerships, and of strenghtening national security through cooperation with less developed countries, considering even the defense area. (ABDENUR; NETO, 2014, p.217).

According to Miyamoto (2009) the presence of Brazil in the Community of Portuguese Language Speaking Countries (Comunidade dos Países de Língua Portuguesa - CPLP) may be viewed from two different perspectives:

[...] on one hand, in the use of it to project Brazilian interests abroad, that is, instrumentality done by the Brazilian foreign policy, aiming at maximizing the use of every possible existing resource, even the occupation of larger spaces than those of other countries along with the nations that are part of the community; on the other hand, it is also possible to infer that, despite the "pragmatism" of its foreign policy, Brazil is also thinking in terms of a joint action with CPLP in order to meet global interests that would not be possible to obtain individually. (MIYAMOTO, 2009, p. 33).

The active foreign policy practiced during the government of President Lula, who traveled in 12 occasions to 29 countries, was quite fruitful to a greater commitment of Brazil in relation to Africa. During the past decade, Brazil opened 19 out of the 37 embassies operating in Africa. Likewise, 18 of the 34 African embassies in Brasilia opened their doors over the same period. According to Visentini (2016), the climax in reaching closer links between Brazil and Africa occured from the beginning of President Lula's 
Luís Gustavo Guerreiro Moreira

government on, through common interests in the struggle against poverty and epidemics, in the implementation of food security policies, and in technology transfer among Southern countries.

Even though President Dilma Rousseff had significantly reduced some global commitments since 2011, cooperation in the scope of ZOPACAS was still a priority. The Brazilian Development Bank (Banco Nacional de Desenvolvimento - BNDES), the Brazilian Cooperation Agency (Agência Brasileira de Cooperação - ABC) and the Brazilian Agricultural Research Corporation (Empresa Brasileira de Pesquisa Agropecuária - EMBRAPA) still maintain several investments in Senegal and Ghana. The opening of a BNDES Office in South Africa at the end of 2013 emphasized the importance that Brazil credits to regional cooperation. Brazil expanded its policies for the development and technical support of the Portuguese-Speaking African Countries (Países Africanos de Língua Portuguesa - PALOP) during the last decade. In the military field, support for the training of the Namibia navy and the work of the Brazilian Cooperation Agency (Agência Brasileira de Cooperação - $\mathrm{ABC}$ ) for military qualification in Cape Verde, São Tomé e Príncipe, Guinea-Bissau, Senegal, Benin, Nigeria and Angola were really significant.

In 2016, Brazil changed the direction of its foreign policy guidelines in relation to Africa. In the current Michel Temer's government, the Ministry of Foreign Affairs, under José Serra, requested a survey to assess the cost of the closing of diplomatic missions in the continent. In September 2016, the minister extinguished the Coordination General of Humanitarian Cooperation and Actions Against Hunger (Coordenadoria Geral de Cooperação Humanitária e Combate à Fome - CGFOME), an institution co-responsible for the international humanitarian cooperation to eradicate hunger and poverty, that used to fulfill an important role in the African continent. This sort of attitude befits the policy of the stripping of the South-South agenda and the guidelines of a foreign policy "without diplomatic grandstanding". 
Priorities for Brazilian Cooperation in the South Atlantic

\section{CONCLUSION}

Supranational regionalism has been one of the most important innovations in governance in recent years. As more and more challenges transcend the national borders, new and more sophisticated mechanisms of regional cooperation become necessary. Natural resources, energy, environmental degradation, disease control, migration, and military incursions are only a few examples of critical phenomena that do not respect national borders. The governance model centered on a hegemonic State is not capable of responding effectively to these dynamics.

The prominent role of Brazil at ZOPACAS has been maintained in recent years. There is a considerable effort from Brazil to consolidate its role as a leading player in a scenario that is full of contingencies. Regarding foreign affairs, the country faces persistent challenges to combine its interests in the South Atlantic with dissuasion to potential threats, besides leading alliances for a heterogeneous array of countries from the western coast of Africa. Internally, it faces the challenge of the dismantling of the foreign policy of the governments of Lula and Dilma, following the realignment to the global powers. The main argument is given in relation to austerity and containment of expenses, a situation caused by the economic crisis experienced by the country.

If the Member Countries of ZOPACAS think that it is necessary to secure non-intervention from extra regional players in order to provide a zone of peace and cooperation, more than simple military cooperation is needed. The establishment of a peace zone without economic and diplomatic integration and technical cooperation may cause the opposite effect; it becomes quite attractive to extra regional powers. The role Brazil plays in South Atlantic integration takes into account the complexity that is inherent to this kind of initiative. Even though the challenges and the frailties are clearly exposed, the efforts are there to minimize the possibility of interference.

Nevertheless, there is the risk that the new guidelines for Brazilian foreign policy in relation to African countries may weaken this tendency, because weaker commercial relations and cooperation from the largest Brazilian companies (especially 
Luís Gustavo GuerreIRO MoreIRA

Petrobras and the major building contractors), involved in corruption scandals and investigated by the courts (Operação Lava Jato) may put in a tight spot Brazilian leadership and the existence of a zone of cooperation in the South Atlantic.

368 | Tensões Mundiais, Fortaleza, v. 21, N. 22, P. 359-368, 2016 